\title{
PERAN PELATIHAN DAN WORKSHOP BAGI PENINGKATAN MOTIVASI, INOVASI DAN KREATIVITAS PADA UMKM KERAJINAN TANGAN DARI MANIK-MANIK
} Santi Riana Dewi ${ }^{1}$, Andari², Martina Rahmawati Masitoh ${ }^{3}$

Program Studi Manajemen Universitas Serang Raya

Email: ${ }^{1}$ santirianadewi@yahoo.co.id, 2andaridharmawan@gmail.com 3martina.r.masitoh@gmail.com

\begin{abstract}
Abstrak
Pengabdian kepada masyarakat ini dilaksanakan oleh dosen pada perguruan tinggi, dalam rangka turut serta berperan aktif di dalam meningkatkan kualitas sumber daya manusia melalui pelatihan dan workshop.Pelatihan dan workshopyang dilakukan berhubungan dengan usaha untuk meningkatkan motivasi, inovasi dan kreativitas pada UMKM, khususnya kerajinan tangan dari manik-manik. Hasil UMKM berupa kerajinan tangan dari manik-manik pada saat ini masih sangat diperlukan untuk terus ditingkatkan. Selain itu pasar untuk produk kreativitas dari manik-manik masih sangat terbuka luas. Adapun hasil dari manik-manik tersebut berupa tasbih dan aneka perhiasan wanita seperti gelang dan kalung. Hasil kerajinan tangan ini dipilih karena cara membuatnya cukup mudah dan bahan-bahan yang diperlukan cukup mudah untuk diperoleh. Metode yang dilakukan pada pengabdian ini adalah dengan partisipative approach, dengan metode pendekatan partisipatif ini para responden terdiri dari masyarakat selaku pelaku usaha. Responden turut serta berperan langsung pada focus grup discussion, wawancara, pelatihan, workshop, konsul, dan eksekusi. Melalui pelaksanaan pengabdian ini diharapkan akan mampu mendorong tumbuh dan berkembangnya UMKM untuk meningkatkan kesejahteraan masyarakat dan meningkatkan kualitas peran aktif para dosen sebagai wujud kepedulian terhadap peningkatan mutu sumber daya manusia di mayarakat.
\end{abstract}

Katakunci: pelatihan, workshop, motivasi, inovasi, kreativitas, dan pendekatan partisipatif.

\section{Abstract}

This community service is carried out by lecturers at the university, in order to participate actively in improving the quality of human resources through counseling and workshops. Counseling and workshops carried out are related to efforts to increase motivation, innovation and creativity in MSMEs, especially handicrafts made from beads. The results of MSMEs in the form of handicrafts from beads are still very much needed to be continuously improved. Besides that the market for bead creativity products is still very widely opened. The results of these beadsare in the form of prayer beads and various women's jewelry such as bracelets and necklaces. The handicrafts are chosen because the method of making them is quite easy and the ingredients needed are easy to obtain. The method used in this service is participatory approach, and the respondents consist of the community as business actors. Respondents also participated directly in the focus group discussion, interviews, training, workshops, consuls, and executions. Through the implementation of this service it is hoped that it will be able to encourage the growth and development of MSMEs to improve community welfare and improve the quality of the active role of lecturers as a form of concern for improving the quality of human resources in the community.

Keywords: training, workshop, motivation, creativity, and partisipative approach.

\section{PENDAHULUAN}

Peran serta perguruan tinggi termasuk para dosen di dalam turut serta mambantu meningkatkan perekonomian masyarakat, salah satunya melalui kegiatan pengabdian kepada masyarakat. Selain itu pengabdian kepada masyarakat merupakan bagian dari pelaksanaan Tri Dharma
Perguruan Tinggi, yang wajib dilakukan oleh para dosen. Pengabdian yang dilakukan pada saat ini berupa upaya meningkatkan peran pelatihan dan workshop untuk peningkatan motivasi, inovasi dan kreativitas dari kualitas dan keanekaragaman produk hasil UMKM. Pengabdian dilaksanakan oleh beberapa dosen 
pada kelurahan Lopang, kecamatan Serang. Hasil poduk UMKM masih perlu ditingkatkan dan membutuhkan inovasi dan kreativitas dari keanekaragaman produk sesuai dengan peminatan dan potensi dari pelaku usaha di masyarakat.

Dikarenakan masyarakat di kelurahan ini merupakan bagian dari perkotaan, sehingga hanya memiliki sedikit sekali hasil kebun atau pertanian. Sehingga UMKM yang perlu dilakukan adalah menghasilkan produkproduk kreatif dan inovatif yang terbuat dari bahan-bahan yang mudah untuk didapatkan. Dengan ini dipilihlah produk berupa tasbih dan periasan wanita yang berupa gelang dan kalung dari manik-manik. Bahan-bahan ini sangat mudah didapatkan di pasar dengan harga yang relatif murah. Seperti diketahui tasbih merupakan hasil kerajinan tangan yang mudah cara pembuatannya dan tasbih selalu digunakan oleh umat islam untuk berzikir ataupun terkadang untuk hiasan, dan juga hadiah. Selain tasbih, manik-manik juga dapat digunakan untuk membuat perhuasaan wanita, seperti gelang dan kalung.

Besar harapan suatu saat nanti kelurahan Lopang bisa menjadi kampung tasbih atau pusat kerajian tangan dari manikmanik. Adapun mengenai pasar produk ini masih sangat terbuka luas. Tantangan pada saat ini adalah bagaimana meyakinkan masyarakat bahwa mereka mampu dan bisa membuat produk-produk dari manik-manik yang memiliki kualitas dan menghasilkan produk yang menarik dan unik. Sehingga akan diminati pasar yang lebih luas di masa yang akan datang.

Pengabdian kepada masyarakat yang dilakukan berupa pemberian motivasi kepada masyarakat agar senantiasa bersemangat, dan terus percaya diri untuk mandiri menghasilkan produk-produk yang nantinya akan memiliki nilai ekonomi, sehingga akan berdampak adanya peningkatan penghasilan. Selain dari itu juga diberikan pelatihan pembuatan produk-produk dari manik-manik, dan workshop. Pelaku usaha diberikan tantangan berkreasi dalam menghasilkan produk, sehingga mampu menumbuhkan kreatifitas dan inovasi masing-masing dari peserta pelatihan dan workshop. Menumbuhkan semangat motivasi bahwa kita pasti bisa, membuat sesuatu yang tadinya terlihat sulit menjadi mudah bahkan menghasilkan produk yang lebih indah dan berkualitas.

Adapun definisi atau konsep dari UMKM Nasional adalah sebagai berikut. Usaha mikro adalah usaha produktif milik perseorangan atau badan usaha perorangan yang memenuhi kriteria usaha mikro. Usaha kecil adalah usaha yang bukan merupakan anak perusahaan atau bukan cabang perusahaan yang memiliki, dikuasai, atau menjadi bagian baik langsung ataupun tidak langsung dari usaha menengah atau besar. Adapun usaha menegah adalah usaha ekonomi produktif yang berdiri sendiri, yang dilakukan oleh orang perorangan atau badan usaha atau cabang perusahaan yang dimiliki, dikuasai, atau menjadi bagian langsung dari usaha menengah atau usaha besar dengan jumlah kekayaan bersih atau hasil penjualan tahunan sebagaimana yang teah diatur di dalam undang-undang. (Undang-undan Republik Indonesia nomer 20 tahun 2008).

Selain hal tersebut di atas yang menjadi fokus dari pengabdian adaalah masalah pelatihan. Pelatihan merupakan proses pengajaran karyawan baru atau yang ada sekarang, ketrampilan dasar yang mereka butuhkan untuk menjalankan pekerjaan mereka. Pelatihan merupakan salah satu usaha untuk meningkatkan sumber daya manusia dalam dunia kerja. Setiap karyawan yang baru ataupun yang sudah lama bekerja perlu mengikuti pelatihan karena adanya tuntutan pekerjaan yang dapat berubah akibat lingkungan kerja, strategi dan lain sebagainya. (Dessler, 2008). Pelatihan yang dilakukan pada pelaksanaan pengabdian ini merupakan pemberian arahan mengenai langkah-langkah yang harus dilakukan untuk menghasilkan produk yang menarik dan memberikan motivasi untuk menghasilkan karya atau produk yang memiliki nilai ekonomi. Adapun 
motivasi adalah semanat kerja yang ada pada pekerja yang membuat pekerja tersebut mampu untuk melakukan pekerjaan sesuai dengan tujuan tertentu yang ingin dicapai. (George \& Jones, 2005). Dorongan yang dilakukan oleh pelatih dan pemateri adalah memberikan semangat bahwa jika kita ingin meningkatkan nilai tambah pada suatu produk maka kita harus berani mencoba halhal yang baru sesuai dengan kebutuhan pasar dan memiliki value dan keunikan. Produkproduk UMKM yang memiliki nilai jual yang baik akan mampu memberikan nilai tambah dan meningkatkan penghasilan dari para pelaku usaha. Untuk menghasilkan produk seperti tersebut maka diperlukan inovasi dan kreativitas. Kreativitas adalah inisiatif terhadap suatu produk atau proses yang bermanfaat, benar, tepat, dan bernilai terhadap suatu tugas yang lebih bersifat heuristic yaitu sesuatu yang merupakan pedoman, petunjuk atau panduan yang tidak lengkap yang akan menuntun kita untuk mengerti, mempelajari atau menemukan sesuatu yang baru (Ernani Hadiyati, 2011). Sedangkan workshop di sini merupakan kegiatan yang dilakukan untuk memberikan cara pengerjaan produk secara individu dan berkelompok untuk menyelesaikan pembuatan produk kerajinan tangan. Selama workshop pelatih akan memberikan teori-teori yang diperlukan dalam pelatihan dan bagaimana mempraktekannya terkait dengan produk yang akan dihasilkan . Sehingga pada akhirnya dapat disimpulkan secara keseluruhan bahwa pelatihan dan workshop yang dilaksanakan pada kegiatan pengabdian merupakan usaha untuk meningkatkan dan membangun ekonomi kreatif dengan cara meningkatkan inovasi dan kreativitas dari produk-produk UMKM. Selain hal tersebut pengabdian kepada masyarakat dapat mengurangi engangguran, meningkatkan kesejahteraan masyarakat, dan meningkatkan mutu sumber daya manusia.

$$
\text { Pada penelitian terdahulu }
$$

menunjukan hasil bahwa terdapat pengaruh secara simultan antara kreatifitas dan inovasi terhadap kewirausahaan. Sedangkan secara parsial pengaruh inovasi terhadap kewirausahaan menunjukan pengaruh yang lebih besar jika dibandingkan dengan pengaruh kreativitas terhadap kewirausahaan. (Ernani Hadiyati, 2011). Penelitian lain menunjukan bahwa kreativitas, inovasi dan kompetensi para pengusaha kecil dapat menentukan baik buruknya usaha. Oleh karena itu peningkatan kreativitas dapat dilakukan melalui pengembangan serta metode pembentukan kreativitas yang menekankan pada beberapa indikator pengkontribuasiannya. Adapun indikatornya adalah keunggulan, ketekunan, pemikiran mandiri, toleransi terhadap keraguan, otonomi, dan percaya diri. Sehingga dapat disimpulkan bahwa kretivitas dan inovasi akan meningkatkan kompetensi kewirausahaan seseorang yang pada akhirnya kontribusi dalam mempertahankan usaha, sehingga pengembangan usaha dapat terwujud. (Deden A.W dan Janivita J.S, 2012). Pada penelitian yang dilakukan oleh leonardo A dan Eddy Madiono.S, menunjukan hasil bahwa terdapat pengaruh positif antara pelatihan terhadap kinerja karyawan, selain itu juga terdpat pengaruh positif dan signifikan antara motivasi dan kinerja karyawan. (Leonardo A \& Eddy .M.S, 2013). Selain itu terdapat pula hasil peneliatian yang menyatakan bahwa motivasi berwirausaha berpengaruh langsung terhadap pertumbuhan usaha. Namun tidak terdapat pengaruh langsung antara motivasi berwirausaha terhada pertumbuhan usaha melalui inovasi produk. (Vivin Oblivia Y, 2013). Sedangkan pada penelitian lainnya menyimpulkan bahwa faktor pendukung dan penghambat peran pemerintah desa dalam pengembangan usaha tasbih dan aksesori, dapat dilihat bahwa faktor pendukung seperti memberikan semangat kerja kepada pengusaha untuk berupaya meningkatkan semangat kerja, mengadakan pelatian, memberikan dukungan untuk menciptakan produk baru. Sedangkan faktor penghambat peran pemerintah desa dalam pengembangan usaha kecil seperti pemasaran, 
pemodalan, ketidakstabilan harga mengakibatkan persaingan tidak sehat antar pengrajin, tidak memiliki label merk kerajinan khas. (Masdinia Septiyana, 2017).

Berdasarkan hasil penelitian sebelumnya tersebut maka pada pengabdian ini dilakukanlah penelitian dengan metode pendekatan partisipatif untuk melihat dampak dari pelatihan dan workshop untuk mendorong meningkatnya motivasi pelaku usaha, dan kreativitas serta inovasi terhadap hasil produk UMKM khususnya pada kerajinan tangan dari manik-manik yang dibuat menjadi tasbih, gelang, dan perhiasan wanita lainnya. Sehingga mampu mendorong meningkatnya kewirausahaan membangun ekonomi kreatif.

Berdasarkan uraian di atas dapat diartikan dengan adanya inovasi produk maka diharapkan akan meluasnya pasar dari produk kerajinan tangan ini nantinya mampu meningkatkan kesejahteraan masyarakat dan mampu mengurangi angka pengangguran dan meningkatkan ekonomi masyarakat pada umumnya. Dan peran perguruan tinggi sebagai penggerak akan mampu memberikan motivasi serta melakukan adanya inovasiinovasi dan kreativitas produk olahan dari UMKM mampu meningkatkan kualitas dari kegiatan pengabdian kepada masyarakat.

Terdapat beberapa permasalahan yang dihadapi berhubungan dengan pelaksanaan program pengabdian masyarakat yaitu sebagai berikut. Pertama masyarakat belum memiliki kemampuan daan motivasi untuk membuat membuat kerajinan tangan dari manik-manik. Kedua, masyarakat belum memiliki keyakinan akan kemampuan mereka untuk menghasilkan pruduk yang kreatif dan inovatif. Ketiga, masyarakat mengetahui nilai jual dari produk yang dihasilkan. Adapun tujuan akhir dari pelaksanaan pengabdian ini adalah menjadi bahan pertimbangan oleh aparatur, pemerintah desa dan pelaku usaha untuk meningkatkan kreasi dan keanekaragaman produk UMKM. Kemudian meningkatkan kerja sama perguruan tinggi dan masyarakat untuk meningkatkan kesejahteraan dan pengembangan desa/kelurahan. Selain itu, dapat dijadikan bahan acuan dan analisa atau gambaran bagi warga dan masyarakat desa/ kelurahan dalam membangun dan mengembangkan potensi di wilayahnya.

\section{METODE PELAKSANAAN}

Pengabdian kepada masyarakat dilaksanakan di kelurahan Lopang kecamatan Serang.Adapun sasarannya adalah meningkatkan kualitas sumber daya manusia melalui pelaksanaan pelatihan dan workshop bagi pelaku usaha di kelurahan agar mampu menghasilkan produk-produk yang kreatif, beranekaragam dan berkualitas. Sasaran berikutnya adalah meningkatkan kerja sama dengan perguruan tinggi melalui pelaksanaan program pengabdian kepada masyarakat yang dilakukan oleh para dosen sebagai upaya peran aktif di dalam pengembangan desa/kelurahan meningkatkan kesejahteraan warga.

Metode yang digunakan dari kegiatan pelatihan pembuatan tasbih dan perhiasan wanita dari manik-manik adalah sebagai berikut. Pelaksanaan kegiatan pengabdian melalui 4 tahap sebagai berikut.

1) Tahap persiapan dan perencanaan Pada tahap persiapan dan perencanaan, dari perguruan tinggi yaitu para pelaksana melakukan identifikasi terhadap permasalah yang dihadapi oleh para pelaku usaha yaitu masyarakat setempat. Kemudian mengidentifikasi siapa saja dari pelaku usaha yang akan mengikuti pelatihan dan workshop. Selain itu pelaksana juga melakukan wawancara dan tanya jawab kepada pelaku usaha. Setelah itu dilakukan persiapan untuk materi pelatihan, bahan-bahan dan peralatan yang akan diperlukan pada pelaksanaan pelatihan dan workshop. Pada tahap ini peran masyarakat turut serta membantu melakukan indentifikasi, dan memberikan info-info dan data yang diperlukan untuk menujang kesuksesan dari kegiatan pengabdian.

2) Tahap implementasi 
Pada tahap impementasi pelaksana memberikan pendampingan, pelatihan dan mengadakan workshop. Adapun masyarakat turut serta berperan aktif dan mengikuti kegiatan dengan penuh antusias dari awal hingga kegiatan selesai. Sehingga dapat terlihat dengan nyata hasil dari kreativitas dan inovasi dari produk kerajinan tangan berupa tasbih, gelang dan kalung dari manikmanik.

3) Tahap evaluasi dan monitoring

Pada tahap evaluasi dan monitoring dosen membuat catatan tentang temuantemuan dari hasil kegiatan pengabdian. Sehingga dapat ditemukan permasalah yang dihadapi pelaku usaha yaitu para peserta yang terkait dengan kuantitas dan kualitas produk yang masih perlu ditingkat atau sudah layak untuk masuk pasar. Pada tahap ini kemudian dilakukan evaluasi untuk menemukan pemecahan masalah yang dihadapi, dan terus dimonitor perkembangan dari pelaksanaan kegiatan.

4) Tahap refleksi

Pada tahap refleksi pelaksana dapat melihat secara jelas dampak, umpan balik, ataupun pengaruh dari pelaksanaan pelatihan dan workshop terhadap peningkatan motivasi, kreativitas dan inovasi dari pelaku usaha UMKM yang memproduksi hasil kerajinan tangan dari manikmanik berupa tasbih, gelang dan kalung. Sehingga dapat memberikan acuan untuk pelaksanaan kegiatan selanjutnya agar mampu meningkatkan target yang dicapai.

Tabel 1. Indikator-Indikator keberhasilan Program Pelatihan dan Workshop.

\begin{tabular}{|c|c|c|c|}
\hline $\begin{array}{l}\mathrm{N} \\
\text { o. }\end{array}$ & Indikator & $\begin{array}{l}\text { Sebelum } \\
\text { Pelatihan\&w } \\
\text { orkshop }\end{array}$ & $\begin{array}{l}\text { Setelah } \\
\text { Pelatihan\&w } \\
\text { orkshop }\end{array}$ \\
\hline 1 & $\begin{array}{l}\text { Pengetah } \\
\text { uan, dan } \\
\text { ketrampil } \\
\text { an }\end{array}$ & $\begin{array}{l}\text { Belum } \\
\text { memiliki } \\
\text { pengetahuan } \\
\text { dan }\end{array}$ & $\begin{array}{l}\text { Bertambah } \\
\text { pengetahuan } \\
\text { dan } \\
\text { ketrampilan }\end{array}$ \\
\hline
\end{tabular}

Peran Pelatihan dan Workshop Bagi Peningkatan Motivasi, Inovasi dan Kreativitas Pada UMKM

Email-santirianadewi@yahoo.co.ic

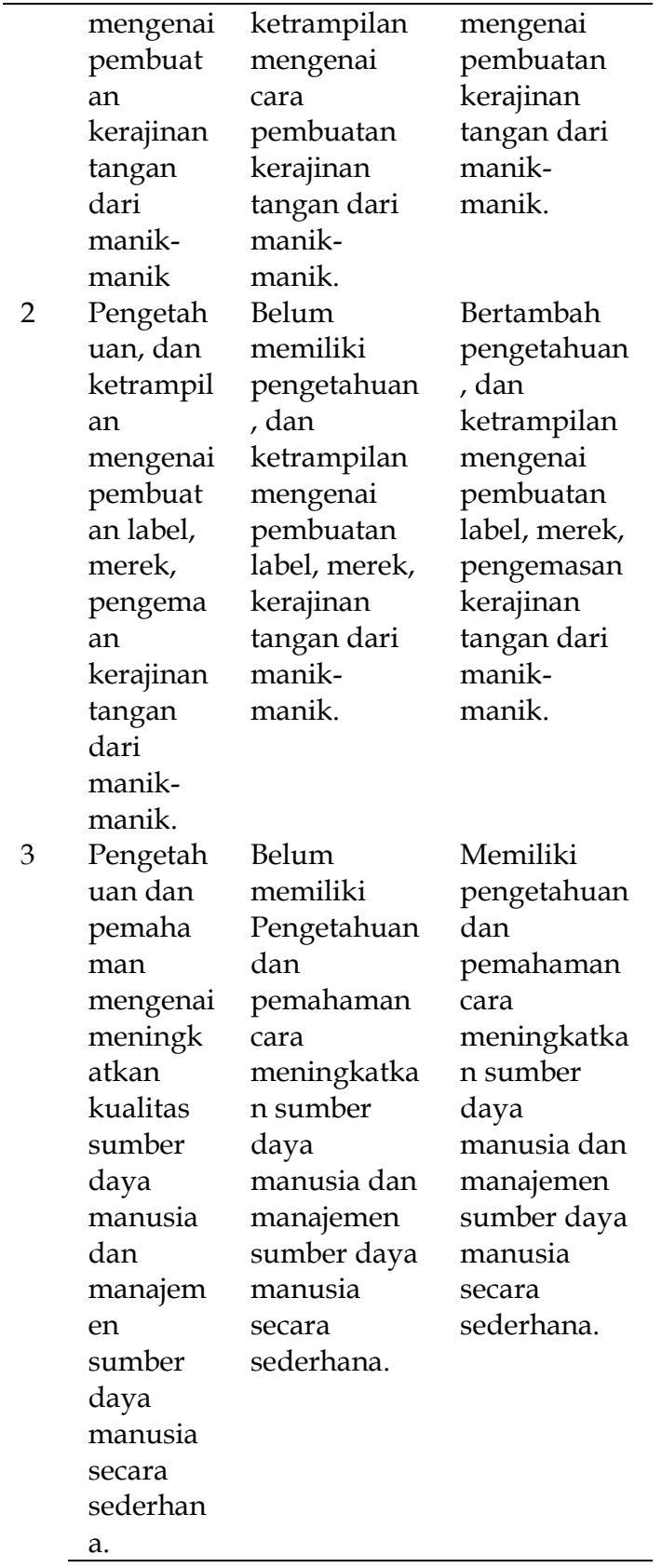

\section{HASIL DAN PEMBAHASAN}

Program pengabdian kepada masyarakat telah diaksanakan dan diharapkan akan terus berkelanjutan dengan programprogram pelatihan dan workshopberikutnya untuk meningkatkan motivasi, inovasi dan kreativitas pada produk kerajinan tangan. Program pengabdian ini dilaksankan di kelurahn Lopang kabupaten Serang. Kegiatan yang dilakukan adalah pelatihan dan workshop untuk meningkatkan inovasi dan kreativitas hasil kerajinan tangan dari manik-manik. Adapun bentuk dari kerajinan tangan tersebut adalah tasbih, gelang, dan kalung. Pada tahap 
awal kegiatan yang dilakukan adalah silaturrahiim kepada bapak lurah dan istri, RW dan RT, sesepuh masyarakat, dan pelaku usaha UMKM di Kelurahan Lopang. Kemudian dilakukan idntifikasi terhadap permasalahan yang ada di masyarakat terutama pelaku usaha UMKM. Setelah itu dilanjutkan dengan sosialisasi program dan kegiatan pelatihan dan workshop, memberikan undangan kepada pelaku usaha, menyiapkan bahan dan peralatan, menentukan tempat, dan waktu pelaksanaan program.

Koordinasi pelaksanaan dibantu oleh ibu lurah, sesepuh masyarakat, bu RW dan bu RT setempat. Adapun persiapan yang dilaksanakan adalah mempersiapkan bahan, alat, tempat, konsumsi, dan perlengkapan penunjang lainnya. Peralatan dan bahan yang diperlukan adalah aneka manik-manik dari batuan atau plastik, gunting, benang plastik, alat bantu jahit dan penunjang lainnya. Mitra usaha di sini terdiri dari para pelaku usaha, ibu-ibu dan wanita dewasa berjumlah 18 orang.

Hasil dari pelaksanaan kegiatan pelatihan dan workshop pembuatan kerajinan tangan dari manik-manik adalah sebagai berikut. Ditemukannya permasalahan yang dihadapi oleh mitra yaitu masyarakat sebagai pelaku usaha UMKM. Pelaksana mampu mengidentifikasi materi-materi yang harus diberikan akan dapat mendorong peningkatan inovasi dan kreativitas dari produk kerajinan tangan yang akan dihasilkan. Selain itu kegiatan ini berhasil mendorong pelaku usaha untuk menghadiri dan mengikuti kegiatan pelatihan dan workshop dengan penuh antusias. Adapun pemateri dari kegiatan ini adalah dosen yang memiliki kompetensi dan kemampuan untuk memberikan pengetahuan dan ketrampilan untuk meningktkan kualitas sumber daya manusia dan implementasi secara sederhana manajemen sumber daya manusia pada khususnya pada masyarakat pelaku UMKM. Sebelum pelaksanaan kegiatan pelaksanan melakukan sosialisasi yang berisikan tentang penyampaian maksud, tujuan, dan target yang ingin dicapai. Setelah itu pelaksana memastikan adanya tempat yang memadai dan terpenuhinya semua bahan dan peralatan yang diperlukan untuk pembuatan kerjinan tangan, materi pelatihan dan pelaksanaan workshop. Dan pada akhirnya pelaksanaan program ini mampu memberi motivasi untuk meningkatkan mutu produk dengan adanya kemampuan untuk melakukan inovasi, mengasah kreatifitas dari pelaku usaha untuk meningkatkan dan menumbuhkan perekonomian mansyarakat melalui produk UMKM yang berkuaitas.

Gambar 1. Kegiatan Pelatihan dan Workshop Pembuatan Kerajinan

Tangan dari Manik-manik.

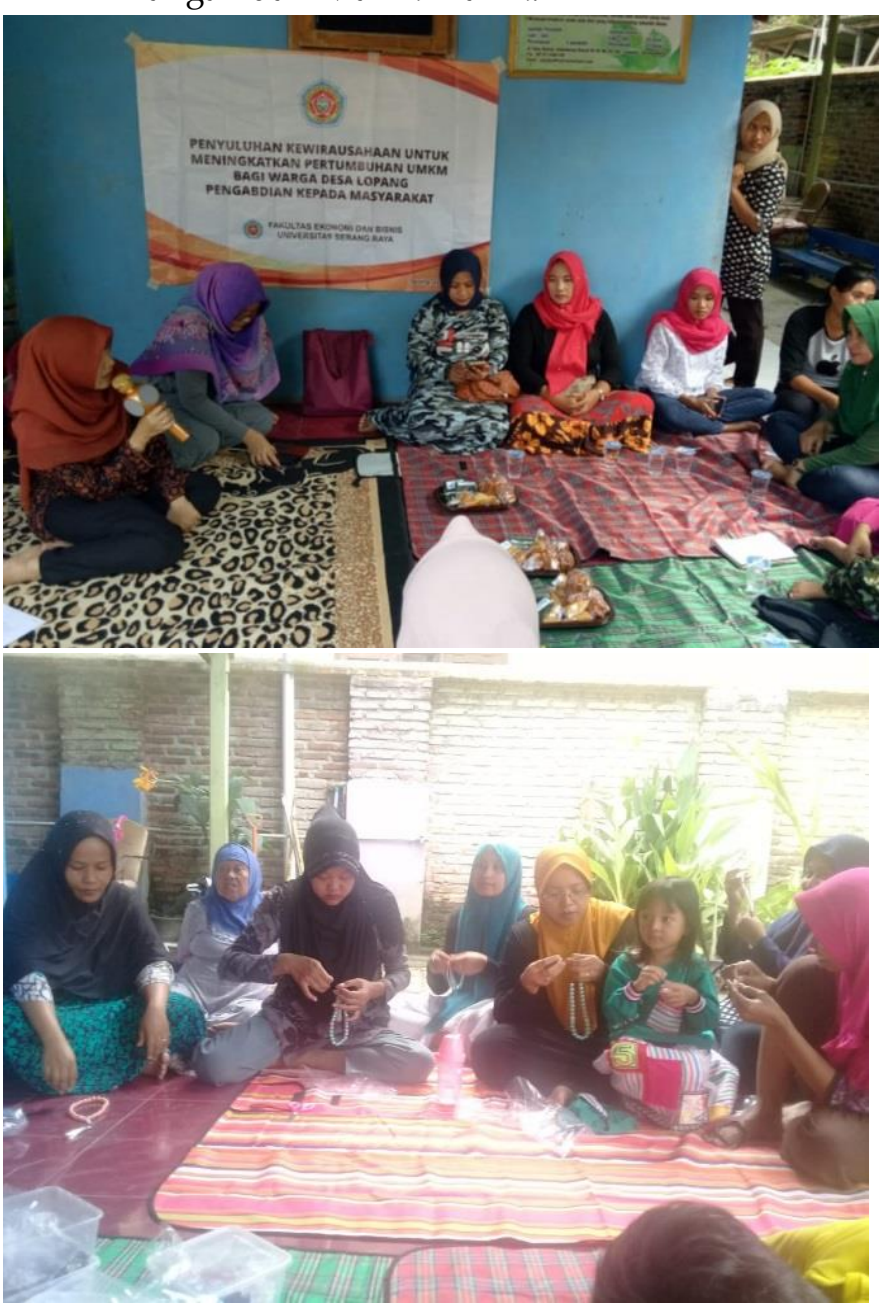

Gambar 2. Hasil Produk Tasbih dan Perhiasan

Wanita 

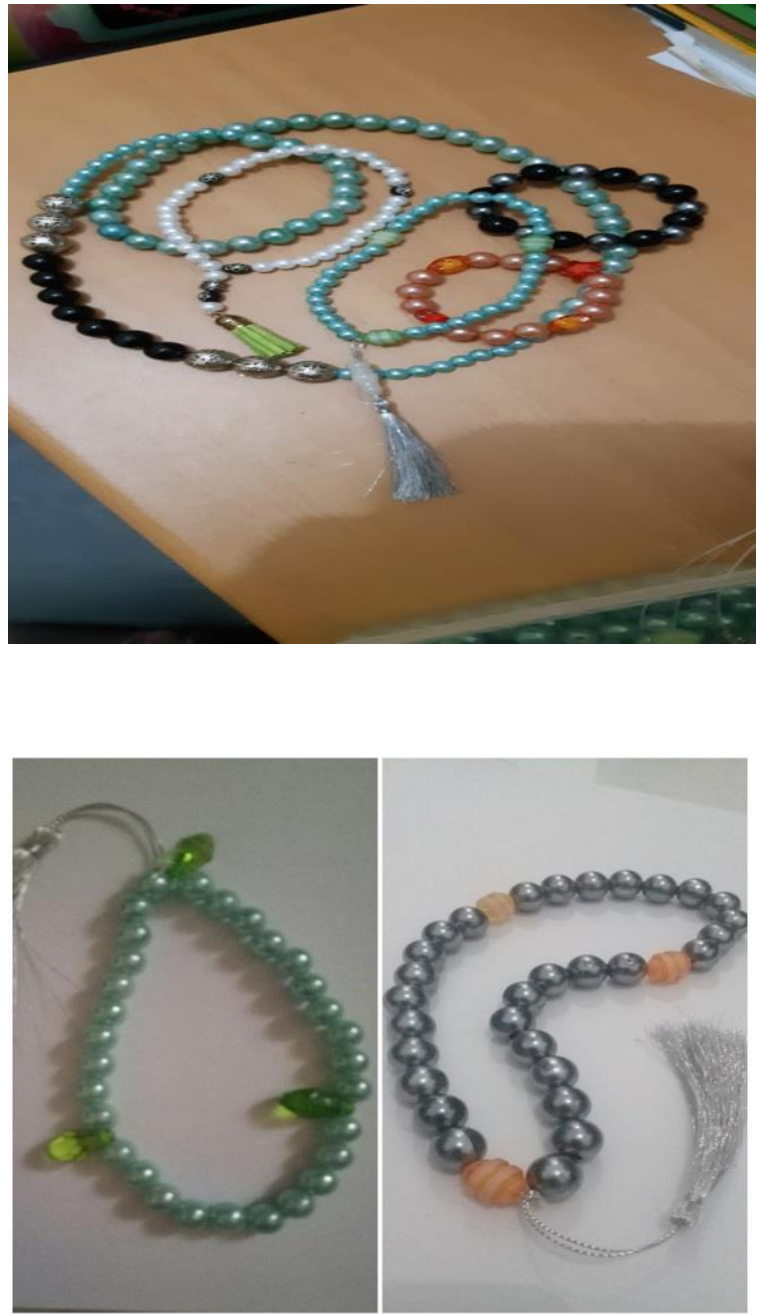

\section{SIMPULAN}

Kegiatan pengabdian kepada masyarakat yang telah dilakukan oleh perguruan tinggi bekerjasama dengan mitra usaha pelaku usaha UMKM memberikan pengaruh terhadap peningkatan motivasi, inovasi dan kreativitas pelaku usaha dengan diadakannya kegiatan pelatihan dan workshop. Peningkatan akan lebih maksimal jika dilakukan secara terus menerus dan berkelanjutan sehingga akan mampu memningaktkan perekonomian masyarakat dengan menumbuhkan inovasi dan kreatifitas terhadap produk-produk yang dihasilkan. Diharapkan dengan produk yang memiliki keunikan dan kualitas yang baik akan memberikan nilai lebih bagi produk dan mampu pada akhirnya memperluas pasar. Selain itu dengan adanya pendampingan,pelatihan dan workshop akan menumbuhkan pembangunan ekonomi kreatif. Diharapkan pada program pengabdian kepada masyarakat di waktu yang akan datang akan dapat melakukan peningkatan kerja sama yang lebih baik lagi antara perguruan tinggi, mitra usaha dan pelaku industri untuk menghasilkan keanekaragaman produk kerajinan tangan, perluasan pangsa pasar dan mutu sumber daya manusia. Bersamaan dengan peningkatan pelaksanaan pelatihan dan workshopmampu menumbuhkan motivasi untuk meningkatkan inovasi dan kreativitas dari usaha UMKM khususnya hasil kerajinan tangan.

\section{DAFTAR REFERENSI}

Dessler.G. (2008). Terjemahan. Manajemen Sumber Daya Manusia. Edisi Kesepuluh. Jilid I. Jakarta: PT. Indeks.

Eddy. M.Susanto, Leonardo Agusta. (2013). Pengaruh dan Pelatihan dan Motivasi Kerja Terhadap Kinerja Karyawan CV Haragon Surabaya. Jurnal Agora, 1(3): 1-9.

George, J.M. \&Jones,G.R. (2005). Understanding and Managing Organizational Behavior (4th ed). New Jersey: Upper Saddle River.

Hadiyati, Ernani. (2011). Kreativitas dan Inovasi Berpengaruh Terhadap Kewirausahaan Usaha Kecil . Jurnal Manajemen dan kewirausahaan, 13(1): 8-16.

Janivita J. S, Deden A.Wahab S. (2012). Kreativitas dan Inovasi Penentu Kompetensi Pelaku Usaha Kecil. Jurnal Manajemen Teknologi 11(01): 1-14.

Septiyana, Masdinia. (2017). Peran Pemerintah Desa dalam Pengembangan Usaha Kecil Tasbih dan Aksesori (Studi Kasus di Desa Tutul Kecamatan Balung Kabupaten Jember. Tesis. Universitas Muhammadiyah Jember.

Vivin Oblivia Yunal. (2013). Analisis Pengaruh Motivasi Berwirausaha dan Inovasi Produk terhadap Pertumbuhan Usaha Kerajinan di Lombok Barat. Jurnal Agora 1(1): 337-347. 